\title{
Does Vitamin B12 Deficiency in Infants Cause Severe Clinical Symptoms Necessitating Intensive Care?
}

\author{
Süt Çocuğunda Vitamin B12 Eksikliği Yoğun Bakım Gerektiren Ağır Bir Klinik Tabloya \\ Sebep Olur Mu?
}

\author{
(1) Neslihan Karakurt ${ }^{1}$, (1) Canan Albayrak1, (1) Nazik Yener 2, (1) Davut Albayrak ${ }^{3}$ \\ 1Ondokuz Mayıs University Faculty of Medicine, Deparment of Pediatrics, Division of Hematology and Oncology, Samsun, Turkey \\ 2Ondokuz Mayıs University Faculty of Medicine, Deparment of Pediatrics, Division of Intensive Care, Samsun, Turkey \\ ${ }^{3}$ Samsun Medical Park Hospital, Clinic of Pediatric Hematology, Samsun, Turkey
}

\section{Abstract}

Introduction: Cobalamin (Cbl) deficient infants are mostly outpatients. Medical literature is very limited concerning infants with severe $\mathrm{Cbl}$ deficiency requiring intensive care. The aim of this study was to describe infants requiring intensive care whose health issues were primarily related to $\mathrm{Cbl}$ deficiency.

Methods: This is a single-center retrospective observational study performed at the pediatric intensive care unit at a children's hospital. Patients aged 6-24 months with low serum Cbl level coexisting with cytopenia (s) and/or macrocytosis, high levels of iron, ferritin and transferin saturation and whose clinical symptoms necessitating intensive care at diagnosis and resolving after Cbl therapy were included. Infants with chronic diseases and birth asphyxia history were excluded.

Results: Seven infants were included in the study. The mean age and $\mathrm{Cbl}$ level at presentation was $11 \pm 5$ months and $50 \pm 27 \mathrm{pg} / \mathrm{mL}$, respectively. The presenting complaints were diarrhea, vomiting, difficulty swallowing, seizure, respiratory distress and cyanosis after feeding. Three patients needed mechanical ventilation. Megaloblastic changes were detected in five patients who underwent bone marrow aspiration. Cerebral atrophy was found in six of the patients on cranial imaging. Only one patient developed neurological disability during long-term follow-up.

Conclusion: This retrospective study was performed to emphasize the importance of $\mathrm{Cbl}$ deficiency in infants requiring intensive care or who had serious deterioration of organ functions. Cbl deficiency in children may lead to life-threatening complications such as respiratory failure or neurological disorders. Prompt diagnosis and immediate treatment may not only be life saving but also improves quality of life in long-term follow-up.

Keywords: Cobalamin deficiency, pediatrics, intensive care, mechanical ventilation

\section{Öz}

Giriş: Kobalamin (Cbl) eksikliği olan bebekler genelde ayaktan hastalardır. Yoğun bakım tedavisi gerektiren Cbl eksikliği olan bebeklerle ilgili literatür sınırlıdır. Bu çalışmanın amacı yoğun bakım gereksinimi olan ve sağlık sorunları asıl olarak Cbl eksikliğine dayanan bebekleri sunmaktır.

Yöntemler: Bu çalışma tek akademik merkezde çocuk yoğun bakım hastalarının geriye dönük analizine dayanmaktadır. Çalışmaya 6-24 ay arası, Cbl seviyesi düşük ve eşlik eden sitopeni (ler), makrositoz, yüksek serum demir, demir bağlama kapasitesi, ferritin düzeyi olan ve yoğun bakım gerektiren klinik semptomları olan ve tedavi sonrası kliniklerinde düzelme olan hastalar dahil edilmiştir. Süreğen hastalığı veya hipoksik doğum öyküsü olanlar dışlanmıştır.

Bulgular: Yedi bebek çalışmaya alındı. Tanıda ortalama yaş ve kobalamin düzeyi $11 \pm 5$ ay ve $50 \pm 27$ pg/mL'ydi. Başvuru şikayetleri diyare, kusma, yutma güçlüğü, nöbet, solunum güçlüğü ve beslenme sonrası morarmaydı. Üç hastanın mekanik ventilasyon gereksinimi oldu. Beş hastanın kemik iliği aspirasyon yaymasında megaloblastik değişiklikler saptandı. Altı hastada serebral atrofi saptandı. Uzun dönem takipte sadece bir hastada nörolojik sekel kaldı.

Sonuç: Bu çalışma yoğun bakım gereksinimi olan ve ciddi organ işlev bozukluğu geçiren, Cbl eksikliği olan bebeklere dikkat çekmek için yapılmıştır. Cbl eksikliği çocuklarda solunum yetmezliği ve nörolojik bozukluk gibi yaşamı tehdit eden komplikasyonlara yol açabilir. Acil tanı ve tedavi yaşam kurtarıcıdır.

Anahtar Kelimeler: Kobalamin eksikliği, çocuk, yoğun bakım, mekanik ventilasyon

Address for Correspondence/Yazışma Adresi: Neslihan Karakurt, Ondokuz Mayıs University Faculty of Medicine, Deparment of Pediatrics, Division of Hematology and Oncology, Samsun, Turkey

E-mail: neslihan.karakurt@omu.edu.tr ORCID ID: orcid.org/0000-0001-5487-9485

Received/Geliș Tarihi: 02.02.2019 Accepted/Kabul Tarihi: 17.03.2019

${ }^{\circ}$ Copyright 2019 by Society of Pediatric Emergency and Intensive Care Medicine

Journal of Pediatric Emergency and Pediatric Intensive Care published by Galenos Yayınevi. 


\section{Introduction}

Vitamin B12 or cobalamin (Cbl) has a variety of biological functions, but above all, it is essential for hematopoiesis and the development of nervous system. Cbl plays essential roles in folate metabolism and in the synthesis of succinyl-coenzyme A. Methylcobalamin is used in many biological methylation reactions, including the methylation of a number of sites within DNA, RNA, and proteins. ${ }^{1,2}$ Five-deoxyadenosylcobalamin is required for the synthesis of succinyl-coenzyme $A$ which plays an important role in the production of energy from lipids, proteins and is also required for the synthesis of heme. ${ }^{1,2}$ $\mathrm{Cbl}$ deficiency may cause increased level of methylmalonic acid and homocysteine in the blood and sometimes hyperglycinuria. ${ }^{3,4} \mathrm{Cbl}$ deficiency leads to pathologic changes in all rapidly dividing cells (including hematopoietic stem cells and gastrointestinal mucosa). ${ }^{5}$

$\mathrm{Cbl}$ deficiency in adults with a mature nervous system may present as megaloblastic anaemia, polyneuropathy, subacute combined degeneration of the spinal cord, dementia or depression. In contrast, in infants who undergo rapid growth and development of the brain; Cbl deficiency may lead to severe neuronal impairment. ${ }^{6}$ The most common symptoms include failure to thrive, hypotonia, irritability, lethargy, developmental delay and even regression, epilepsy or movement disorder. ${ }^{6}$ In late infacy and early childhood, neurological symptoms such as mental deterioration, encephalopathy, spastic paresis (subacute combined degeneration), extrapyramidal signs and neuropathy may be observed. ${ }^{7}$ Although nutritional $\mathrm{Cbl}$ deficiency in infancy was described in $1962^{8}$ and several times thereafter, clinical spectrum of the disease has not yet received enough attention.

In Turkey, nutritional Cbl deficiency is a very common health issue due to poor intake of animal derived food which may be a result of low socioeconomic status. Since a normal newborn has sufficient vitamin B12 stores to last for six to eight months, Cbl deficiency presenting at less than six months of age is observed only in breast fed infants of $\mathrm{Cbl}$ deficient mothers. ${ }^{9-11}$

Cbl deficient infants who require medical attention are mostly outpatients. Medical literature is very limited concerning infants with severe $\mathrm{Cbl}$ deficiency requiring intensive care. ${ }^{12-}$

${ }^{14}$ The aim of this study was to describe infants receiving intensive care whose health issues were primarily related to Cbl deficiency.

\section{Material and Methods}

This is a retrospective observational study using medical records of all the pediatric patients hospitalized at the Samsun Ondokuz Mayıs University Faculty of Medicine, Children's
Hospital, Pediatric Intensive Care Unit (PICU), from July 2005 to July 2017 who had a low Cbl level $(<200 \mathrm{pg} / \mathrm{mL})$. Patients aged 6-24 months without any chronic diseases and history of birth asphyxia were included in the study. Inclusion criteria were low serum Cbl level coexisting with any of cytopenia (s), macrocytosis, high levels of iron, ferritin and transferrin saturation at diagnosis with clinical symptoms necessitating intensive care and improvement in the laboratory values (decreased levels of iron, ferritin or transferin saturation) and/or clinical status after Cbl therapy. Those with a positive direct antiglobulin test or suspected hemophagocytic syndrome (HLH) (high ferritin level with other diasgnostic criteria of HLH: fever, splenomegaly, a fibrinogen level $<1.5$ $\mathrm{g} / \mathrm{L}$, hemophagocytosis in bone marrow, and a triglyceride level $>295 \mathrm{mg} / \mathrm{dL}$ ) were excluded. Improvement in clinical status included discharge from PICU, improved oral feeding and responding to environmental stimuli, resolution of neurological symptoms and presentation complaints such as respiratory failure. The diagnosis of megaloblastic anemia was established withmegaloblastic changes in the bone marrow with cytopenia (s). Demographical features, clinical presentations on admission, indications for $\mathrm{PICU}$, laboratory findings, and bone marrow aspiration findings (if done) were recorded. Since the patients required emergent PICU admission, detailed evaluation of the level of neurological deterioration, such as inability to hold head, sit without support or crawl, could not be done.

The study was performed in accordance with the principles of the Declaration of Helsinki and approved by the Ethics Committee of the Ondokuz Mayıs University Faculty of Medicine.

The $\mathrm{Cbl}$ and ferritin levels were measured by electrochemiluminescence immunoassay (Roche $\left.{ }^{\circledR}\right)$. Serum iron was measured using the colorimetric method (Roche ${ }^{\circledR}$ ). Complete blood count was measured using an automated analyzer (Beckman LH750®). Homocysteine level was measured by high performance liquid chromatography (Agilent ${ }^{\circledR}$ ). According to the laboratory kits, the normal range for $\mathrm{Cbl}$ in serum was $200-800 \mathrm{pg} / \mathrm{mL}$, ferritin -20-275 $\mathrm{ng} / \mathrm{mL}$, iron -60-158 $\mathrm{gg} / \mathrm{dL}$, folic acid $-4.6-18.7 \mathrm{ng} / \mathrm{mL}$ and homocysteine -5-14 $\mu \mathrm{mol} / \mathrm{L}$. Minimum detectable level of Cbl was $30 \mathrm{pg} / \mathrm{mL}$.

All the data were evaluated by SPSS version 18. Mean was used as central tendency criterion for data with normal distribution and median for data without normal distribution.

\section{Results}

During the period of study, 94 children with low Cbl levels were hospitalized in the PICU. 52\% of the patients were younger 
than 24 months of age $(n=49)$. After further evaluation of medical information and laboratory results, and exclusion of chronic diseases and history of birth asphyxia, autoimmune cytopenia (s) and $\mathrm{HLH}$, the findings of seven children (girl/ boy ratio $=3 / 4$ ) were considered to be primarily related to $\mathrm{Cbl}$ deficiency and these seven patients formed the study group. The mean age was $11 \pm 5$ months (Table 1). The complaints on admission were diarrhea, vomiting, difficulty swallowing, seizure, respiratory distress and cyanosis after feeding (Table 2).

All patients had a history of exclusive breastfeeding for six months. After six months of age, they could not tolerate weaning or refused supplementary food. The mother of the first patient shown on Table 1, 2, 3 had a low Cbl level (60 $\mathrm{pg} / \mathrm{mL}$ ). However, data regarding the nutritional status and serum Cbl levels of the mothers were not available.

Two patients had a body weight below the $3^{\text {rd }}$ and four patients had a body weight below the $10^{\text {th }}$ centile. Two patients had hypotonia on admission. They neither could hold their head, nor sit without support. Hypotonia resolved after therapy. After therapy, improvement of clinical and laboratory status was observed within one month. All patients, except one, looked around with interest, had eye contact, seated with support and were able to swallow food. One patient's (number six) neurological status did not show significant improvement after Cbl therapy.

On admission, the mean $\mathrm{Cbl}$ level was $50 \pm 27 \mathrm{pg} / \mathrm{mL}$. Five patients had pancytopenia with severe anemia (Table 1). Table 3 shows the changes in laboratory parameters before and after $\mathrm{Cbl}$ treatment. Ferritin, transferrin saturation and iron level before $\mathrm{Cbl}$ therapy were above the normal limits in all patients. They were also measured in four patients after $\mathrm{Cbl}$ therapy and a downward trend was observed. Due to the low number of cases, statistical analysis could not be performed. Homocysteine levels were above normal limits in four patients before therapy.

Megaloblastic changes were detected in five patients who underwent bone marrow aspiration. Cerebral atrophy was detected in six patients on cranial imaging. Children with respiratory distress and/or difficulty swallowing had lobar pneumonia and needed mechanical ventilation (Table 1). All infants received parenteral $\mathrm{Cbl}$ for treatment.

The sixth patient had one hour lasting seizure before emergency department admission. He was the second child of a mother aged 19 years. Cbl status of the mother was not known. He was immediately intubated and given

\begin{tabular}{|c|c|c|c|c|c|c|c|c|c|c|}
\hline Patient & $\begin{array}{l}\text { Age } \\
\text { (months)/ } \\
\text { gender }\end{array}$ & $\mathrm{Hb}(\mathrm{g} / \mathrm{dL})$ & $\begin{array}{l}\text { MCV } \\
\text { (fL) }\end{array}$ & $\begin{array}{l}\text { WBC } \\
\left(\times 10^{9} / L\right)\end{array}$ & $\begin{array}{l}\text { ANC }^{2} \\
\left(\times 10^{9} / \mathrm{L}\right)\end{array}$ & $\begin{array}{l}\mathrm{Plt}^{3} \\
\left(\times 10^{9} / \mathrm{L}\right)\end{array}$ & $\begin{array}{l}\text { Body weight } \\
\text { (kg) }\end{array}$ & $\mathrm{Tx}^{4}$ & $M A^{5}$ & Cranial MRI \\
\hline 2 & $20 / F$ & 3.4 & 100 & 1.8 & 0.5 & 20 & $5.6(<3 P)$ & + & + & Cerebral atrophy \\
\hline 3 & $8 / \mathrm{M}$ & 5.7 & 106 & 6.0 & 0.6 & 20 & $6.5(3-10 P)$ & + & + & Cerebral atrophy, delay in myelination \\
\hline 6 & $6 / \mathrm{M}$ & 12.2 & 73 & 10.0 & 4.0 & 260 & $6.5(10 P)$ & - & + & $\begin{array}{l}\text { Cerebral atrophy, corpus callosum } \\
\text { atrophy, hydrocephalus }\end{array}$ \\
\hline 7 & $6 / F$ & 12.0 & 82 & 15.6 & 14.0 & 170 & $N A^{5}$ & - & $N A^{6}$ & Cerebral atrophy \\
\hline
\end{tabular}

Table 2. Symptoms, signs and clinical findings on admission and neurological outcomes of infants with cobalamin deficiency admitted to PICU

\begin{tabular}{|c|c|c|c|c|c|c|c|c|}
\hline Patient & $\begin{array}{l}\text { Cyanosis } \\
\text { after feeding }\end{array}$ & $\begin{array}{l}\text { Respiratory } \\
\text { distress }\end{array}$ & $\begin{array}{l}\text { Difficulty in } \\
\text { swallowing }\end{array}$ & $\begin{array}{l}\text { Diarrhea, } \\
\text { vomiting }\end{array}$ & Seizure & $\begin{array}{l}\text { Mechanical } \\
\text { ventilation (days) }\end{array}$ & $\begin{array}{l}\text { Hypotonia } \\
\text { on admission }\end{array}$ & $\begin{array}{l}\text { Improvement in } \\
\text { neurological status } \\
\text { after treatment }\end{array}$ \\
\hline 1 & + & + & + & - & + & $+(25)$ & + & + \\
\hline 3 & - & - & + & + & - & - & - & + \\
\hline 4 & - & + & + & - & + & $+(7)$ & + & + \\
\hline 6 & - & - & - & - & + & $+(3)$ & - & - \\
\hline 7 & - & - & - & - & + & - & - & + \\
\hline
\end{tabular}


Table 3. Laboratory parameters before and after cobalamin treatment

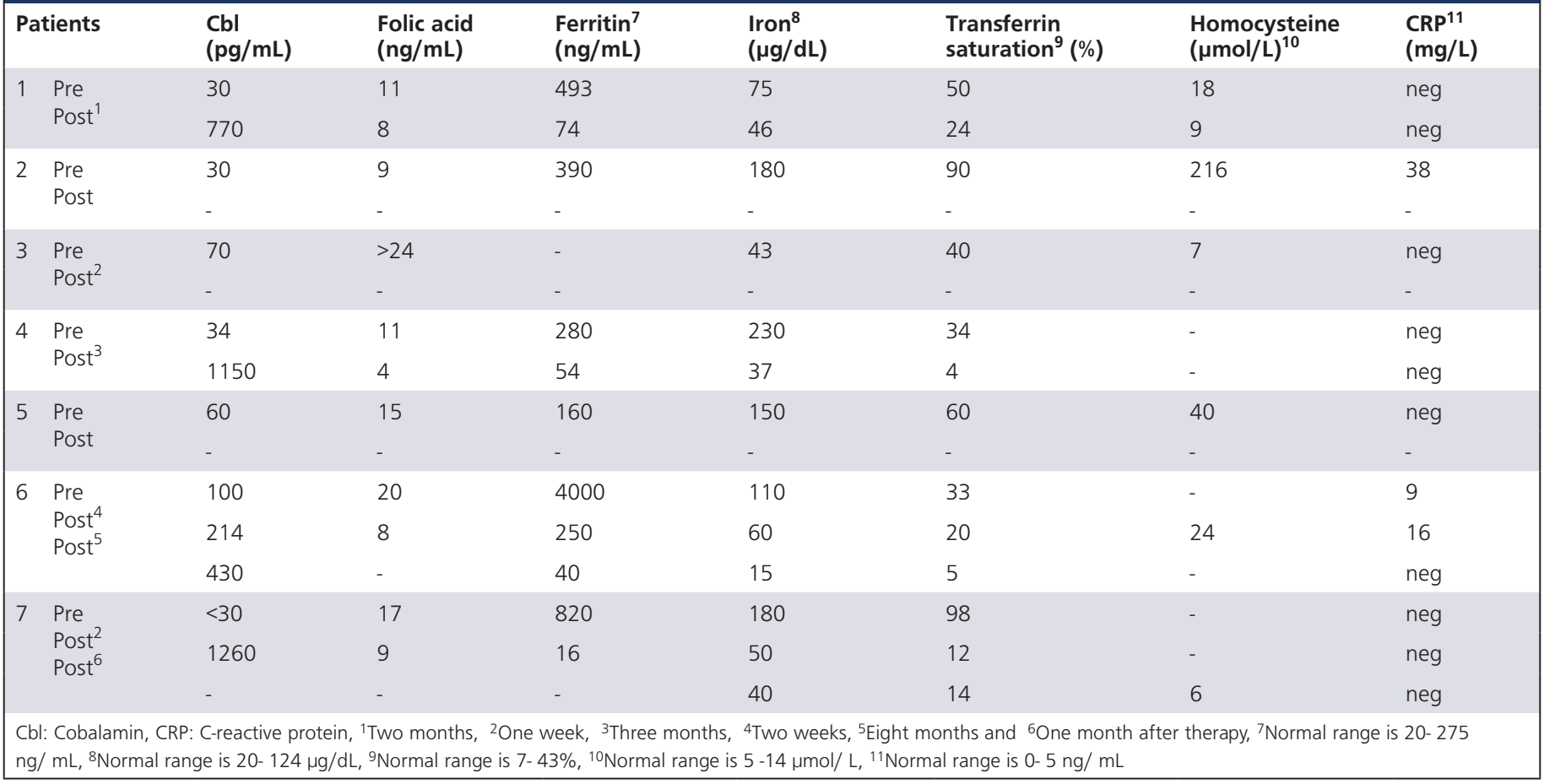

antiepileptics. He did not have a history of birth asphyxia or a diagnosis of epilepsy prior to admission. Inborn errors of metabolism were excluded in this patient. At present time, as a six-year-old boy, he has mental and motor retardation.

\section{Discussion}

In the US, the prevalence of $\mathrm{Cbl}$ deficiency in children has been reported to be $1-3 \%{ }^{15,16}$ whereas a high prevalence of up to $40 \%$ has been described in children of developing countries due to malnutrition. ${ }^{17,18}$ In developed countries, clinical manifestation is restricted to breast-fed infants of either vegetarian or vegan mothers, whereas in developing countries the prevalence is high because of low socioeconomic status and poor nutritional state.

In this study, seven infants with Cbl deficiency were described. All cases had serum Cbl levels below 100 pg/mL, which may be considered severe deficiency. In addition, serum ferritin and iron levels and transferrin saturation percentages were high at admission whereas they decreased after therapy. Although our patient number was inadequate, we observed that iron was utilized after Cbl therapy. We believe that increased succinyl-CoA production could increase heme synthesis and thus iron use and rapidly reduce serum iron levels as suggested in recent literature. ${ }^{19}$

Three Cbl deficient infants in the PICU suffered from respiratory failure and/or cyanosis after feeding on admission. All had lobar pneumonia which was attributed to aspiration and received mechanical ventilation. Also, all had feeding difficulties. The findings of respiratory failure and pneumonia were compatible with the literature. ${ }^{20,21}$ lodice et al. ${ }^{14}$ reported a 45-day-old patient with $\mathrm{Cbl} C$ defect presenting with isolated pulmonary hypertension which could be the result of increased levels of homocysteine and subsequent vascular injury. Considering the similarities of consequences of metabolic and nutritional $\mathrm{Cbl}$ disorders, sub-clinical pulmonary hypertension may be an important underlying pathology for respiratory problems as well. In addition, severe anemia might contribute to respiratory distress and sucking and feeding issues.

Neurological consequences of Cbl deficiency are also of great interest. Hyperglycinemia has been considered a causative factor for neurological disturbances in X-linked Cbl disorder (HCFC1) mimicking nonketotic hyperglycinemia. ${ }^{22}$ Scalais et al. ${ }^{22}$ reported a newborn with $\mathrm{x}$-linked $\mathrm{Cbl}$ disorder mimicking nonketotic hyperglycinemia with intractable seizures, severe neurocognitive deficit, increased cerebrospinal fluid glycine and methylmalonic acid levels, whose laboratory results improved with Cbl therapy. There are limited data concerning the role of glycine in $\mathrm{Cbl}$ deficiency. ${ }^{3,4,19}$ Glycine acts as an inhibitory and excitatory amino acid in the central nervous system. Increased glycine in the cerebrospinal fluid may have excitatory effects on N-methyl-D-aspartate receptors resulting in intractable seizures. On the other hand, it has inhibitory effects on brainstem and spinal cord causing hypotonia and apnea. ${ }^{19}$ We speculate that in nutritional Cbl deficiency, insufficient synthesis of succinyl-CoA cannot fully meet the 
appropriate synthesis of glycine resulting in inadequate heme synthesis. Excess glycine might possibly fail to be eliminated by cleavage enzyme and deposits in the tissues. We believe that swallowing problems, vomiting, respiratory failure and seizures may be related to secondary hyperglycinemia in $\mathrm{Cbl}$ deficiency.

Two of our patients had growth retardation and four had a body weight at the $10^{\text {th }}$ centile or below. Anthropometric parameters of one patient were unavailable. We could not show any data about the etiology of low serum $\mathrm{Cbl}$ levels in the patients. However, all infants were exclusively breastfed. Although data regarding nutritional status of the mothers could not be obtained, considering the high prevalence of poor nutritional state including consumption of animal derived food in pregnant women and mothers, we believe that $\mathrm{Cbl}$ deficiency in infants was related to nutritional $\mathrm{Cbl}$ deficiency in mothers.

Five Cbl deficient infants had vomiting, difficulty swallowing and diarrhea on admission. Resistance to consuming food during weaning period, diarrhea and vomiting have been described in the literature. $6,18,23,24$

Five of our patients had afebrile seizure on admission. The vital signs and biochemical work-up were normal. Cerebral atrophy was determined in all of them. However, one had atrophy of the corpus callosum and hydrocephaly as well. These findings were speculated to be related to neurological disturbances associated with $\mathrm{Cbl}$ deficiency as described above. Epilepsy was reported as a rare manifestation of $\mathrm{Cbl}$ deficiency. Honzik et al. ${ }^{6}$ reported that among 17 infants with profound $\mathrm{Cbl}$ deficiency, two infants had seizures. Moreover, few reports described a causal relationship with manifestation of West syndrome. ${ }^{25,26}$

Following prompt diagnosis and therapy, six of $\mathrm{Cbl}$ deficient patients recovered clinically. One patient developed mental and motor retardation after diagnosis and treatment of $\mathrm{Cbl}$ deficiency. He presented with seizure lasting for one hour before emergency department admission and hypoxy might have contributed to neurological deficits.

Five $\mathrm{Cbl}$ deficient patients had megaloblastic anemia. Megaloblastic anemia is the most common finding of $\mathrm{Cbl}$ deficiency. ${ }^{27}$ But patients may present without macrocytosis and megaloblastic anemia as well.

Cerebral atrophy was detected in six patients. Cerebral atrophy related to $\mathrm{Cbl}$ deficiency has been described. 6,27,28 The most common neuro-radiological findings are cortical atrophy, hypoplasia of the corpus callosum, retardation in myelinisation and moderate enlargement in the ventricles. ${ }^{28}$ One of our patients had cerebral atrophy with delay in myelination and one had cerebral atrophy with thinning of the corpus callosum and hydrocephaly.
The limitations of our study are; the analysis of urine/plasma methylmalonic acid and serum holotranscobalamin levels, which are the most concrete methods used to identify $\mathrm{Cbl}$ deficiency, were not available at the authors' institution. Since it is a retrospective study, the data concerning detailed physical examination including body length, head circumference, detailed neurological examination and current contact information of families were not available in some children.

\section{Conclusion}

In this study, seven infants with Cbl deficiency who received intensive care were reported and three of them received mechanical ventilation. Management of $\mathrm{Cbl}$ deficiency is well known for outpatients. This study was performed to emphasize the importance of $\mathrm{Cbl}$ deficiency in patients requiring intensive care or who had serious deterioration in organ functions. Cbl deficiency may lead to life threatening complications such as respiratory or neurologic complications. We suggest that infants with nutritional $\mathrm{Cbl}$ deficiency due to maternal diet may present with a severe clinical picture requiring intensive care. Cbl deficiency at any age in childhood, especially during infancy, may aggravate the severity of symptoms of the existing disease. Prompt diagnosis and immediate treatment may not only be life saving but may also improve quality of life in long term. It may be appropprite to check the Cbl levels in infants receiving intensive care, feed Cbl-deficint diet and having symptoms of acute onset neurological, respiratory, gastrointestinal or cardiac deterioration.

\section{Acknowledgements}

We thank Prof. Dr. Emin Kansu for his valuable discussion in preparation of this manuscript.

\section{Ethics}

Ethics Committee Approval: The study was performed in accordance with the principles of the Declaration of Helsinki and approved by the Ethics Committee of the Ondokuz Mayıs University, Faculty of Medicine.

Informed Consent: Retrospecive study.

Peer-review: Externally and internally peer-reviewed.

\section{Authorship Contributions}

Surgical and Medical Practices: N.K., C.A., D.A., N.Y., Concept: N.K., C.A., Design: N.K., N.Y., Data Collection or Processing: N.K., Analysis or Interpretation: N.K., D.A., Literature Search: N.K., Writing: N.K.

Conflict of Interest: No conflict of interest was declared by the authors.

Financial Disclosure: The authors declared that this study received no financial support. 


\section{References}

1. Pearson AG, Turner AJ. Folate-dependent 1-carbon transfer to biogenic amines mediated by methylenetetrahydrofolate reductase. Nature. 1975;13;258:173-4.

2. Shane B. Folic acid, vitamin B-12, and vitamin B-6. In: Stipanuk M, (Ed), Biochemical and Physiological Aspects of Human Nutrition. 2nd ed. Philadelphia W.B. Saunders Co; 2000;483-518.

3. Emery ES, Homans AC, Colletti RB. Vitamin B12 deficiency: a cause of abnormal movements in infants. Pediatrics. 1997;99:255-6.

4. Higginbottom MC, Sweetman L, Nyhan WL. A syndrome of methylmalonic aciduria, homocystinuria, megaloblastic anemia and neurologic abnormalities in a vitamin B12-deficient breast-fed infant of a strict vegetarian. N Engl J Med. 1978;17;299:317-23.

5. Graham SM, Arvela OM, Wise GA. Long-term neurologic consequences of nutritional vitamin B12 deficiency in infants. J Pediatr. 1992:121:710-4

6. Honzik T, Adamovicova M, Smolka V, Magner M, Hruba E, et al. Clinical presentation and metabolic consequences in 40 breastfed infants with nutritional vitamin B12 deficiency-what have we learned? Eur J Paediatr Neurol. 2010;14:488-95.

7. Reynolds E. Vitamin B12, folic acid, and the nervous system. Lancet Neurol. 2006;5:949-60.

8. Jadhav M, Webb JK, Vaıshnava S, Baker SJ. Vitamin B12 deficiency in Indian infants. A clinical syndrome. Lancet. 1962;2:903-7.

9. Andrews NC, Ullrich CK, Fleming MD. Disorders of iron metabolism and sideroblastic anemia. In: Orkin SH, Nathan DG, Ginsburg D, Look AT, Fisher DE, Lux SE, eds. Nathan and Oski's Hematology of Infancy and Childhood. 7th ed. Philadelphia: Saunders Elsevier; 2009;521-71.

10. McPhee AJ, Davidson GP, Leahy M, Beare T. Vitamin B12 deficiency in a breast fed infant. Arch Dis Child. 1988;63:921-3.

11. Bjørke Monsen $A L$, Ueland $P M$, Vollset $S E$, Guttormsen $A B$, Markestad T, et al. Determinants of cobalamin status in newborns. Pediatrics. 2001;108:624-30

12. Abu-Kishk I, Rachmiel M, Hoffmann C, Lahat E, Eshel G. Infantile encephalopathy due to vitamin deficiency in industrial countries. Childs Nerv Syst. 2009;25:1477-80.

13. Codazzi $D$, Sala F, Parini $R$, Langer $M$. Coma and respiratory failure in a child with severe vitamin $\mathrm{B}(12)$ deficiency. Pediatr Crit Care Med. 2005;6:483-5.

14. Iodice FG, Di Chiara L, Boenzi S, Aiello C, Monti L, et al. Cobalamin $C$ defect presenting with isolated pulmonary hypertension. Pediatrics. 2013;132:e248-51.

15. Rasmussen SA, Fernhoff PM, Scanlon KS. Vitamin B12 deficiency in children and adolescents. J Pediatr. 2001;138:10-7.

16. Black MM. Effects of vitamin B12 and folate deficiency on brain development in children. Food Nutr Bull. 2008;29:S126-31.

17. McLean ED, Allen LH, Neumann CG, Peerson JM, Siekmann JH, et al. Low plasma vitamin B-12 in Kenyan school children is highly prevalent and improved by supplemental animal source foods. I Nutr. 2007;137:676-82.

18. Demir N, Koc A, Üstyol L, Peker E, Abuhandan M. Clinical and neurological findings of severe vitamin B12 deficiency in infancy and importance of early diagnosis and treatment. J Paediatr Child Health. 2013;49:820-4.

19. Bicakci Z. Growth retardation, general hypotonia, and loss of acquired neuromotor skills in the infants of mothers with cobalamin deficiency and the possible role of succinyl-CoA and glycine in the pathogenesis. Medicine (Baltimore). 2015;94:e584.

20. Akcaboy M, Malbora B, Zorlu P, Altınel E, Oguz MM, et al. Vitamin B12 deficiency in infants. Indian J Pediat. 2015;82:619-24.

21. Codazzi $D$, Sala F, Parini R, Langer M. Coma and respiratory failure in a child with severe vitamin $B(12)$ deficiency. Pediatr Crit Care Med. 2005;6:483-5.

22. Scalais E, Osterheld E, Weitzel C, De Meirler L, Mataigne F, et al. X-Linked cobalamin disorder (HCFC1) mimicking nonketotic hyperglycinemia with increased both cerebrospinal fluid glycine and methylmalonic acid. Pediatr Neurol. 2017;71:65-9.

23. Zengin E, Sarper N, Caki Kiliç S. Clinical manifestations of infants with nutritional vitamin B deficiency due to maternal dietary deficiency. Acta Paediatr. 2009;98:98-102.

24. Ünal S, Rupar T, Yetgin S, Yaralı N, Dursun A, et al. Transcobalamin II Deficiency in Four Cases with Novel Mutations. Turk J Haematol. 2015:32:317-22.

25. Glaser K, Girschick HJ, Schropp C, Speer CP. Psychomotor development following early treatment of severe infantile vitamin B12 deficiency and West syndrome-is everything fine? A case report and review of literature. Brain Dev. 2015;37:347-51.

26. Malbora B, Yuksel D, Aksoy A, Ozkan M. Two infants with infantile spasms associated with vitamin B12 deficiency. Pediatr Neurol. 2014;51:144-6.

27. Dror DK, Allen LH. Effect of vitamin B12 deficiency on neurodevelopment in infants: current knowledge and possible mechanisms. Nutr Rev. 2008;66:250-5.

28. Rossi A, Cerone R, Biancheri R, Gatti R, Schiaffino MC, et al. Earlyonset combined methylmalonic aciduria and homocystinuria: neuroradiologic findings. AJNR Am J Neuroradiol. 2001;22:554-63. 